\title{
FORMULATION OF STRATEGY FOR COMPETITIVENESS IMPROVEMENT OF GENERAL INSURANCE COMPANY IN INDONESIA
}

\author{
Natasha Nabila*, Indrawan R. Dikky, Saptono Imam Teguh \\ School of Business, IPB University, Bogor, Indonesia \\ *E-mail: blanatasha25@gmail.com
}

\begin{abstract}
The decline in underwriting income and economic instability during the COVID-19 pandemic prompted companies to decide on the right strategy to survive and continue growing and having a competitive advantage in the general insurance industry. This study aims to identify the external and internal environment; formulate alternative strategies as well; determine priority strategies and managerial implications in increasing competitiveness at PT XYZ. The analytical techniques used in this research are foresight analysis, Porter's Five Forces analysis, PEST analysis, internal analysis, VRIO analysis, EFE and IFE analysis, IE Matrix (Internal External), and Quantitative Strategic Planning Matrix (QSPM). The company's position is in cell V, namely hold and maintain conditions, with the recommended strategy is market penetration and product development. Alternative strategies can develop (1) increasing promotion; (2) expanding product distribution channels; (3) developing existing products; (4) adding features on the mobile application in retail business units. The corporate business unit can (1) improve HR training, (2) recruit employees, and (3) develop new products according to consumer needs. The priority strategy for PT XYZ is increasing promotion in retail business and developing new products in corporate business units.
\end{abstract}

\section{KEY WORDS}

Competitiveness, COVID-19, foresight, general insurance, porter five forces, strategy.

Insurance is one of the non-bank financial services industries, which plays a role in minimizing risks that may occur in the future. Insurance is divided into general insurance and life insurance (Law 2014). Public awareness regarding insurance philosophy is still considered low. In 2020, the penetration rate of the insurance industry will only reach $4 \%$. The insurance industry penetration rate is still lower than Singapore, which has gained $7 \%$. The low penetration rate is also due to the low level of insurance literacy. The insurance literacy index only reached $19.4 \%$, lower than the banking index, which had gained $36.12 \%$. Furthermore, the insurance inclusion rate reached $13.15 \%$ compared to the banking index, which had reached $73.88 \%$ (OJK 2020).

In March 2020, the World Health Organization designated COVID-19 as a pandemic (WHO 2020). The spread of the COVID-19 virus is calculated to spread very quickly compared to previous pandemics. To prevent the COVID-19 virus, the Government of the Republic of Indonesia has implemented Large-Scale Social Restrictions (PSBB) by closing schools and businesses, restricting economic activities that lead to physical contact, and restricting international travel (Ministry of Health 2020). The COVID-19 pandemic has caused health problems and economic and political problems in the affected countries (Bartik et al. 2020). The COVID-19 pandemic has had an impact on the Indonesian economy. Indonesia's economic growth in the second quarter of 2020 recorded negative growth of $5.32 \%$. Negative economic growth in the second quarter was caused by the policy of limiting community activities implemented in almost all parts of Indonesia (BPS 2021).

The business situation in the affected countries is getting worse and worse due to the loss of jobs and lives (Babuna et al. 2020). The COVID-19 pandemic has affected almost every business worldwide, including the insurance industry. The decline in premium income during the COVID-19 pandemic occurred in several countries such as Ghana, North Macedonia, Ethiopia, and India (Babuna et al. 2020; Stojkoski et al. 2020; Worku and Mersha 2020; Parvathi and Lalitha 2021). Pandemic also affected insurance by decreasing 
insurance density and penetration rate in China and Bangladesh (Wang et al. 2020; Haque et al. 2021). In the second quarter, general insurance premium income in Indonesia recorded negative growth of $6.1 \%$ during the COVID-19 pandemic (AAUI 2020).

PT $X Y Z$ is a company engaged in the general insurance industry. PT $X Y Z$ is a public company. In the last five years, PT XYZ has experienced a decline in underwriting income. Revenue underwriting is income earned from the principal activities of the insurance company (IAI 1994). In 2015 PT XYZ's underwriting income was 211 billion Rupiah, and in 2019 it was only 152.8 billion Rupiah. PT XYZ's premium income has decreased during the COVID-19 pandemic. PT XYZ recorded insurance premium income in 2020 at only 107 billion Rupiah compared to 2019 is 152 billion Rupiah.

The decline in underwriting income and economic instability during the COVID-19 pandemic prompted companies to formulate appropriate strategies to survive and continue to grow and have a competitive advantage in the insurance industry. This research was conducted to formulate a strategy to increase the competitiveness of PT XYZ. This research has differences from previous research. Previous research has research objects consisting of life insurance companies (Sulastri et al. 2019; Prakoso 2020), BPJS employment (Nofrizal 2017; Wandebori 2019), and reinsurance companies (Andayani 2019).

Strategy formulation to increase competitiveness uses several analytical techniques. Previous research used Porter's five forces analysis technique (Adriana and Sunitiyoso 2015; Manuel 2016) to analyze competition in the insurance industry and combine it with PEST analysis to obtain external factors from the macro environment (Utomo et al. 2019). VRIO analysis is used to analyze internal factors that can be a competitive advantage (Johan 2018). Furthermore, determining the company's position and formulating alternative strategies using the IE matrix (Anindea et al. 2016) and determining priority strategies using QSPM (Dewi et al. 2018; Alamanda et al. 2018). This study adds a foresight analysis to see the driving factors for changes in the general insurance industry which were previously also carried out in the children's toy industry and the banking industry (Anindea et al. 2016; Budiman et al. 2020). This research is novel in the conditions faced by the company at the time this research was conducted which is during the COVID-19 pandemic

The objectives of this research are as follows: (1) identify the external and internal environment at PT XYZ, (2) formulate alternative strategies in increasing daytime power at $\mathrm{PT} X Y Z$, and (3) formulate priority strategies and implications managerial in increasing competitiveness at PT XYZ.

\section{METHODS OF RESEARCH}

This research uses a descriptive qualitative approach. The research was conducted from December 2020 to December 2021. This research was conducted at PT XYZ, a general insurance company located in South Jakarta. The types of data used are primary data and secondary data. Primary data was obtained through filling out questionnaires and interviews.

Furthermore, secondary data in this study are data from literature studies, publications, and scientific journals. The sample selection was determined by one of the purposive sampling methods, namely expert sampling (judgment sampling). Expert sampling in this study consisted of three internal respondents, namely stakeholders at PT YXZ, and two external respondents, namely experts in general insurance.

The stages of business strategy formulation at PT XYZ go through three stages, namely 1) the data collection stage (the input stage), 2) the matching stage (the matching stage), 3) the decision stage (the decision stage) (David and David 2016). At the data collection stage, the analysis carried out is the analysis of foresight, industry competition, external factors, internal factors, and external and internal factors. At the stage of matching, the analysis carried out is to formulate an alternative strategy, while at the decision stage, the analysis carried out is to determine the priority strategy.

A foresight analysis was conducted to determine the drivers of change in the general insurance industry in the next 20 years. Future analysis was carried out using the Delphi method and cross-impact analysis using MICMAC software and ended with preparing future 
scenarios. The Delphi method is a complex problem-solving process by effectively communicating in groups (Afshari 2019). In this study, the Delphi method determines the key factors that will affect the general insurance industry. Next, the cross-impact analysis uses MICMAC software to determine the drivers of change in the general insurance industry (Godet et al. 2007). It ends with preparing future scenarios (Alizadeh and Soltanisehat 2020).

External factors were identified through questionnaires and interviews with five respondents. Industry competition analysis uses Porter's five forces analysis technique. Porter's five forces analysis is carried out by analyzing the parameters of Porter's five forces, namely the level of industry competition, the bargaining power of buyers, the bargaining power of suppliers, the threat of new entrants, and the threat of substitute products that influence the general insurance industry (Porter 2008). Furthermore, the analysis of external factors based on the macro-environment uses PEST analysis. PEST analysis is a framework that categorizes elements of a company's external environment such as political, economic, social, and technological elements (Thompson et al. 2006).

Internal factors were identified through questionnaires and interviews with three internal respondents. Internal factors are determine by comparing the company's past performance and significant competitors. VRIO analysis is used to assess the potential of the company's resources and capabilities that can be categorized as a sustainable competitive advantage (Grant et al., 2014). The results of identifying external and internal factors are then analyzed on the EFE and IFE matrices to determine the company's opportunities, threats, strengths, and weaknesses (David and David 2016). Formulating alternative strategies and determining company position using the IE matrix and prioritizing strategies using QSPM (David and David 2016).

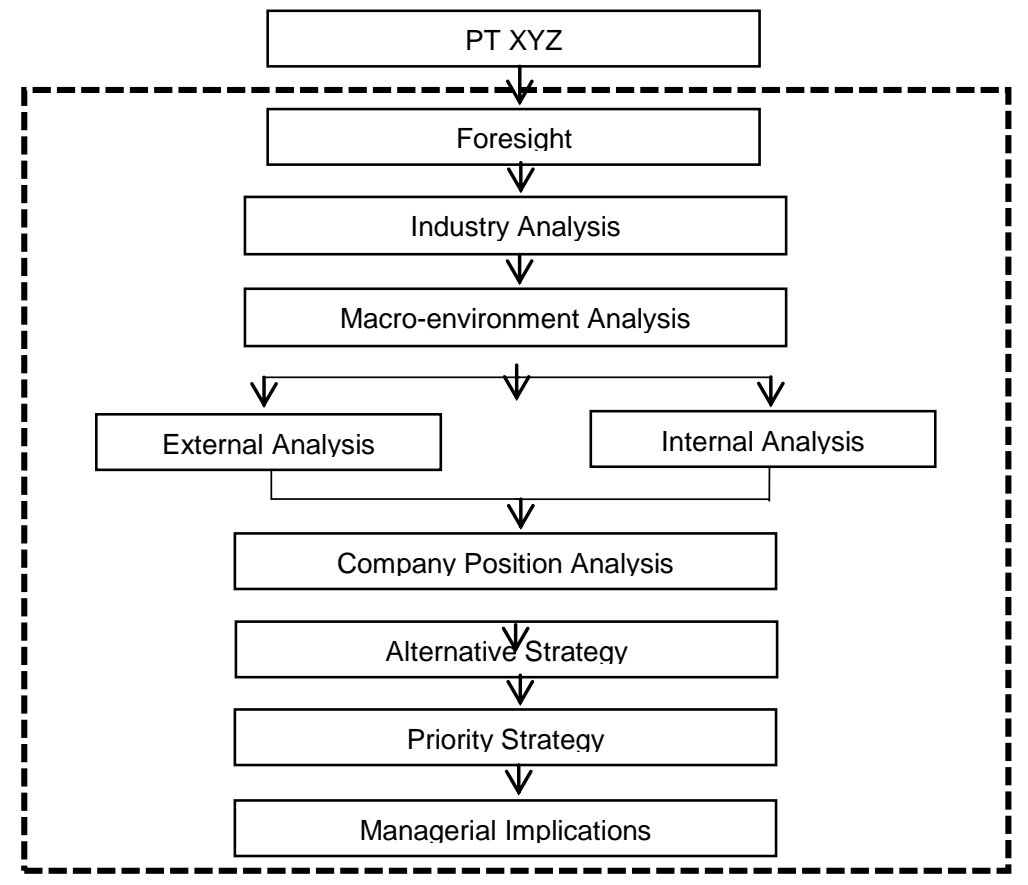

Note: Scope of Research

Figure 1 - Mind Map of the Research

\section{RESULTS AND DISCUSSION}

PT XYZ was established in Bandung on June 25, 1979. PT XYZ has two unit businesses which are retail and corporate. The retail business unit offers property, motor vehicle and travel insurance products. The corporate business unit offers fire, motor vehicle, engineering, freight forwarding, project underwriting and miscellaneous insurance. Based on the business unit, PT XYZ's revenue in 2020, the retail business unit is Rp. 9.3 billion with a 
percentage of $15.56 \%$, and the corporate business unit is $\mathrm{Rp} .49 .5$ billion with a percentage of $84.14 \%$.

Based on an analysis using the Delphi method, five key factors affect the general insurance industry: economic stability, climate change, insurance awareness, the industrial revolution 4.0, and the post-COVID-19 pandemic. The key factors resulting from the Delphi method are then carried out by cross-impact analysis. The results of the cross-impact analysis using MICMAC software show that the climate change factor in quadrant $I$ is the influential variable with a strong influence and a low level of dependence. Climate change factors are also categorized as driving forces. Economic stability, the industrial revolution 4.0, and after the COVID-19 pandemic lies in quadrant II as an intermediate variable with a strong influence and dependence. Factors in quadrant II have a sensitive nature and significantly affect other variables. Furthermore, the insurance awareness factor in quadrant III is the resultant variable with low influence and high dependence. Other variables strongly influence factors that are in quadrant III.

The climate change factor is categorized as a driving factor for changes in the general insurance industry in the next 20 years. In the next 20 years, the frequency and intensity of natural disasters caused by climate change will increase. Climate change harms not only environmental factors but also social factors. A prolonged drought to storms can affect economic stability in the affected region. The government is increasingly promoting climate change impact mitigation to minimize significant impacts. The mitigation movement aims to increase public awareness in using environmentally friendly products and indirectly increase general insurance awareness (insurance awareness).

The development of the insurance industry in Indonesia in the next 20 years will experience changes in the products offered and distribution channels. Insurance companies will provide personalized products and products that support climate change impact mitigation. Personalized products are products that are suited to customer needs. Information related to customer needs is not only based on the information provided but also obtained from external devices that combine machine learning, artificial intelligence (AI), and internet of things (IoT) technologies. Examples of products that support climate change mitigation include property insurance products and motor vehicle insurance that use green technology. In the next 20 years, insurance companies will combine offline and online distribution channels. This is influenced by changes in people's behavior during the COVID19 pandemic who prefer to buy products online.

Porter's five forces analysis is used to analyze competition in the general insurance industry. The analysis results show that all variables affect the general insurance industry. The variable threat of new entrants has the highest value and dramatically affects the general insurance industry. Based on Porter's five forces analysis, some factors affect the general insurance industry, namely the low level of product differentiation (threat of new entrants), standard products (bargaining power of buyers), the threat of forward integration (bargaining power of suppliers), affordable substitute product prices (threat of substitute products) and the number of companies in the general insurance industry (competition between similar competitors).

The results of the PEST analysis show that on the political element, the factors that influence $\mathrm{PT} X Y Z$ are regulations related to insurance digitalization, regulations for implementing IFRS 17 (international financial reporting standard) and regulations on PAYDI (Insurance product associated with investments) sales in general insurance. In the economic element, the influencing factors are the financial and business sluggishness during the COVID-19 pandemic and the projected growth of general insurance premiums in 2021. On the social element, the influencing factors are insurance literacy and the policy of limiting community activities during the COVID-19 pandemic. In the technological element, the influencing factor is big data based marketing, and the Insurtech movement will affect the general insurance industry.

Internal analysis is done by analyzing each division at PT XYZ which underwriting and reinsurance divisions; claims division; finance division; marketing division; HR, Operations and IT division. Internal analysis is also carried out by comparing the company with its 
closest competitors by looking at business segments, marketing, human resources, operations, and finance. PT XYZ has two competitors, PT A and PT B. What they have in common is a conventional general insurance company with a gross premium of 250 billion fewer than 500 billion.

VRIO analysis is used to evaluate competitive resources and capabilities and can be used to analyze the company's strengths and weaknesses (Wandrial 2011). Internal factors in the VRIO analysis are the results of previously carried out internal studies. The results of the VRIO analysis show that all internal factors do not have a sustainable competitive advantage. PT XYZ has two factors categorized as temporary competitive advantage and strengths for the company, namely mobile applications and ISO certification. These are valuable resources or capabilities, and few companies have the same advantages.

Furthermore, the level of underwriting results in 2020, the ratio based on capital risk, the company has established good corporate governance, has an integrated IT system, and the company's work culture is categorized as competitive parity and becomes a strength for the company. These factors are valuable but also shared by most competitors, so they cannot be a competitive advantage. Other factors, namely the level of loss ratio claim, marketing level, business segment, distribution channel, human resources, market share, turnover rate, and income level, are categorized as competitive with no competitive disadvantage and weakness for the company.

The EFE matrix is used to evaluate the opportunities and threats owned by PT XYZ. The total weighted value in the EFE matrix is 2.518 , so this indicates that the company can take advantage of opportunities and minimize threats well. The factor that becomes the foremost opportunity for PT XYZ is big data based marketing with a weighted value of 0.275 . Big data based marketing makes it easy for PT XYZ to create and market products that meet customer needs. Meanwhile, the main threat for PT XYZ is the application of IFRS 17, with a weighted value of 0.241 . The implementation of IFRS 17 will threaten PT XYZ because it requires qualified human resources and technology. The external factor evaluation matrix can be seen in Table 1.

Table 1 - External factor evaluation matrix (EFE)

\begin{tabular}{|c|c|c|c|}
\hline External factors & Weight & Rating & $\begin{array}{l}\text { Weighted } \\
\text { value }\end{array}$ \\
\hline \multicolumn{4}{|l|}{ Opportunity } \\
\hline Regulations related to insurance digitization & 0.067 & 3 & 0.201 \\
\hline Projected growth of insurance premium income in 2021 & 0.069 & 3 & 0.206 \\
\hline General insurance literacy rate is low & 0.087 & 3 & 0.260 \\
\hline Big Data based Marketing & 0.069 & 4 & 0.275 \\
\hline \multicolumn{4}{|l|}{ 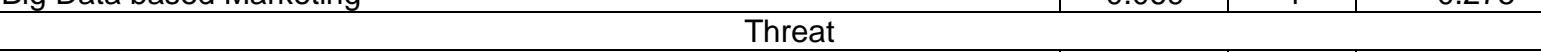 } \\
\hline Insurtech movement & 0.070 & 1 & 0.070 \\
\hline Preparation for the application of IFRS 17 & 0.080 & 3 & 0.241 \\
\hline PAYDI sales in the general insurance industry & 0.070 & 3 & 0.209 \\
\hline Low level of product differentiation & 0.068 & 3 & 0.204 \\
\hline Economic and business sluggishness during the COVID-19 pandemic & 0.068 & 2 & 0.136 \\
\hline $\begin{array}{l}\text { Implementation of the policy of limiting community activities during the } \\
\text { COVID-19 pandemic }\end{array}$ & 0.077 & 3 & 0.230 \\
\hline The products offered are standard products & 0.077 & 3 & 0.153 \\
\hline Suppliers have the ability to become distributors (forward integration) & 0.060 & 2 & 0.119 \\
\hline The price of substitute products is more affordable & 0.073 & 2 & 0.147 \\
\hline Number of companies in the general insurance industry & 0.067 & 1 & 0.067 \\
\hline Total weighted score & & & 2,518 \\
\hline
\end{tabular}

The IFE matrix is used to evaluate the strengths and weaknesses of PT XYZ. The total weighted value in the IFE matrix is 2,295, indicating that the company has not been able to take advantage of its strengths and minimize weaknesses properly. The results of the IFE matrix analysis show that the main strength factor for PT XYZ is that the company already has a mobile application with a weighted value of 0.264 each. Mobile applications can increase product sales. Meanwhile, the main weakness of PT XYZ is that human resource 
management is not optimal, with a weighted value of 0.154 each. HR is a company asset and must be appropriately managed. The internal factor evaluation matrix can be seen in Table 2.

Table 2 - Matrix of internal factor evaluation (IFE)

\begin{tabular}{|c|c|c|c|}
\hline Internal factors & Weight & Rating & $\begin{array}{c}\text { Weighted } \\
\text { value }\end{array}$ \\
\hline \multicolumn{4}{|c|}{ Strength } \\
\hline Underwriting yield rate in 2020 & 0.069 & 3 & 0.207 \\
\hline Ratio based capital risk & 0.072 & 3 & 0.216 \\
\hline Implementation of Good Corporate Governance & 0.058 & 3 & 0.174 \\
\hline Integrated IT system & 0.067 & 3 & 0.202 \\
\hline Good work culture & 0.055 & 3 & 0.164 \\
\hline The company already has ISO & 0.060 & 4 & 0.180 \\
\hline Mobile app & 0.066 & 4 & 0.264 \\
\hline \multicolumn{4}{|c|}{ Weakness } \\
\hline The level of loss ratio claims in 2020 & 0.063 & 2 & 0.127 \\
\hline Marketing fee rate in 2020 & 0.048 & 2 & 0.096 \\
\hline Small business segment & 0.073 & 1 & 0.073 \\
\hline Employee turnover rate & 0.075 & 2 & 0.150 \\
\hline Market share rate & 0.082 & 1 & 0.082 \\
\hline Company income level & 0.070 & 2 & 0.141 \\
\hline Few distribution channels & 0.066 & 1 & 0.066 \\
\hline HR management is not optimal & 0.077 & 2 & 0.154 \\
\hline Total weighted score & & & 2,295 \\
\hline
\end{tabular}

The matching stage uses the IE matrix analysis technique. The IE matrix (InternalExternal) is used to analyze the company's position and formulate alternative strategies by combining the EFE and IFE matrix analysis results. The total weighted value in the EFE matrix is 2.518, and the IFE matrix analysis is 2.295 , so the position of PT XYZ based on the IE matrix is in cell V, namely the hold and maintain strategy. The recommended strategies are market penetration and product development strategies (David and David 2016).

The formulation of alternative strategies is based on strategic recommendations generated from the results of the IE matrix analysis, namely market penetration strategies and product development strategies. Alternative strategies are arranged in two business units at PT $X Y Z$, namely the retail business unit and the corporate business unit. Strategy formulation is also based on the needs of each business unit.

Alternative strategies for retail and corporate business units are market penetration and product development strategies. In the retail business unit, the market penetration strategy focuses on increasing promotions, expanding distribution channels, and product development strategies by developing existing products and adding features to mobile applications. Furthermore, the alternative strategy in the corporate business unit is a market penetration strategy by recruiting new employees and increasing HR training, and product development strategies are carried out by creating new products that suit consumer needs.

The last stage of strategy formulation is the decision stage using QSPM. QSPM determines priority strategies from several alternative strategies resulting from the IE matrix analysis. QSPM analysis was carried out on two business units at PT XYZ, namely the retail business unit and the corporate business unit. The results of the QSPM analysis on the retail business unit show that the priority strategy for $P T X Y Z$ is to increase promotions with a STAS (sum total attractive score) value of 3.62. The priority strategies for the corporate business units can be seen in Table 3 .

Table 3 - Retail business unit priority strategies

\begin{tabular}{|l|c|c|}
\hline \multicolumn{1}{|c|}{ Alternative strategy } & STAS & Priority \\
\hline Increase promotion & 3.62 & I \\
\hline Expanding product distribution channels & 3.55 & II \\
\hline Develop existing products according to consumer needs & 3.29 & III \\
\hline Adding features to the mobile application & 2.38 & IV \\
\hline
\end{tabular}


Furthermore, the results of the QSPM analysis on the corporate business unit show that the priority strategy for PT XYZ is to develop new products according to consumer needs with a STAS value of 3.98 . The priority strategies for the corporate business units can be seen in Table 4.

Table 4 - Corporate business unit priority strategies

\begin{tabular}{|l|c|c|}
\hline \multicolumn{1}{|c|}{ Alternative strategy } & STAS & Priority \\
\hline Develop new products according to consumer needs & 3.98 & I \\
\hline Recruiting new employees & 3.04 & II \\
\hline Improve HR training & 2.86 & III \\
\hline
\end{tabular}

The analysis results at the decision stage with the QSPM show that the priority strategy for PT $X Y Z$ is to increase promotions in the retail business unit and develop new products in the corporate business unit. Although the chosen priority strategy is to grow to advertise and create new products, other alternative strategies can be carried out simultaneously or sequentially based on their respective priority levels following the results of the QSPM analysis. Managerial implications of PT XYZ are summarized in Table 5.

Table 5 - Managerial implications

\begin{tabular}{|c|c|}
\hline \multicolumn{2}{|c|}{ Strategy to survive and maintain PT XYZ } \\
\hline Retail business unit & Corporate business unit \\
\hline $\begin{array}{l}\text { 1. Market penetration strategy } \\
-\quad \text { Increase promotion } \\
\checkmark \quad \text { Increase promotion through social } \\
\\
\checkmark \quad \text { media } \\
\begin{aligned} \text { - Expand distribution channels } \\
\checkmark \quad \text { Cooperating with marketplaces and } \\
\text { digital wallet applications }\end{aligned}\end{array}$ & $\begin{array}{l}\text { 1. Market penetration strategy } \\
\text { Recruiting new employees } \\
\checkmark \quad \text { Recruiting new employees in the marketing } \\
\text { division } \\
\text { - Improve HR training } \\
\checkmark \quad \text { Improve HR training related to product } \\
\checkmark \quad \begin{array}{l}\text { Increasedge } \\
\text { certification in the insurance sector }\end{array} \\
\end{array}$ \\
\hline $\begin{array}{l}\text { 2. Product development strategy } \\
\text { - Develop existing products according to } \\
\text { consumer needs } \\
\checkmark \quad \text { Develop usage-based insurance } \\
\text { products } \\
\text { - Adding features to the mobile application } \\
\checkmark \quad \text { Add online claim feature } \\
\end{array}$ & $\begin{array}{l}\text { 2. Product development strategy } \\
\text { - Develop new products according to consumer } \\
\text { needs } \\
\checkmark \quad \text { Developing green technology insurance } \\
\quad \text { products }\end{array}$ \\
\hline
\end{tabular}

PT XYZ's market penetration strategy in the retail business unit is to increase promotions and expand distribution channels. PT XYZ can improve promotion through social media and content marketing. Promotion through social media can use Youtube. Youtube was chosen because it is the most used social media in 2020 (Kemp 2021). Promotion through Youtube can be done by actively disseminating information related to the products offered and activities organized by the company. Social media marketing can be combined with doing content marketing. Distributed content can be in the form of the provided products related to current social issues. Furthermore, PT XYZ can also expand distribution channels by collaborating with marketplaces and digital wallet applications. Partnerships between insurance companies and digital platforms can reach previously underserved populations.

PT XYZ's product development strategy in the retail business unit is to develop existing products and add features to the mobile application. Product development can already be done by developing usage-based insurance products. The product lines that can be developed into usage-based products are property, motor vehicle and miscellaneous insurance. Furthermore, the addition of features to the mobile application can be done by adding an online claim feature. The addition of the online claim feature can increase customer satisfaction

PT XYZ's market penetration strategy in the corporate business unit is to recruit new employees and improve HR training. The recruitment of new employees is carried out to minimize the risks due to the high employee turnover rate in 2020. Furthermore, PT XYZ can 
improve HR training related to product knowledge and increase the number of certified employees in the insurance sector. PT XYZ's product development strategy in the corporate business unit is to develop new products according to consumer needs. PT XYZ can develop new products related to green technology. New product development is based on the analysis results of the following review, which shows that climate change is the driving factor of change (driving forces). Products that can be developed are commercial property insurance and equipment damage insurance products.

\section{CONCLUSION}

The analysis of external factors indicates that the main opportunity for PT XYZ is big data marketing, with the main threat being the application of IFRS 17. The results of the internal factor analysis show that the main strength of PT XYZ is that the company has a mobile application with the main weakness is human resource management, that is not optimal. The position of the company based on the IE matrix analysis is in cell V, namely the hold and maintain function. An alternative strategy for PT XYZ in the retail business unit is to increase promotions, expand distribution channels, develop existing products, and add features to the mobile application. An alternative strategy for PT XYZ in the corporate business unit is recruiting new employees, increasing HR training, and developing new products according to consumer needs. The priority strategy for PT XYZ is to increase promotions in the retail business unit and create new products in the corporate business unit.

PT $X Y Z$ should implement the resulting priority strategy, namely increasing promotions in the retail business unit and developing new products in the corporate business unit to increase the company's competitiveness in the general insurance industry. Further research can be conducted on the formulation of strategies in general insurance and life insurance companies in Indonesia. Further research can also add analytical tools like the Boston consulting group (BCG) and SWOT. BCG analysis can analyze the market share of each business unit of PT XYZ. SWOT matrix can be used to formulate alternative strategies based on the company's opportunities, threats, strengths, and weaknesses.

\section{REFERENCES}

1. [AAUI] Indonesian General Insurance Association. (2020). Performance and Analysis of Indonesia's General Insurance \& Reinsurance Industry Quarter 2 (Jan-Jun) 2020. http://aaui.or.id/. [23 August 2020].

2. Adriana, D., \& Sunitiyoso, Y. (2013). Developing a differentiation strategy of a captive insurance companies case study of PT XYZ. IJBA 2(4):396-403.

3. Alamanda, D.T., Anggadwita, G., Raynaldi, M., Novani, S., Kijima, K. (2019). Designing strategies using IFE, EFE, IE and QSPM analysis digital village case. The Asian Journal of Technology Management 12(1): 48-57.

4. Alizadeh, R., \& Soltanisehat, L. (2020). Stay competitive in 2035: a scenario-based method to foresight in the design and manufacturing industry. Foresight 22(3):309-330.

5. Andayani, A. (2019). Formulation of a competitive strategy for PT Reasuransi Indonesia Utama (Persero)/ Indonesiare in the marine insurance business. [thesis]. Yogyakarta: Gadjah Mada University.

6. Anindea, F., Baga L.M., Rifin, A. (2016). Analysis of competition SMEs wooden educational toys: case study of CV Omocha Toys. IJSR 5(9): 619-622.

7. Afshari, A. R. (2019). Using the delpi method for future studies. In: Proceedings of the International Conference on Industrial Engineering and Operations Management; Pilsen 23-26 July 2019. http://ieomsociety.org/pilsen2019/papers/69.pdf [13 November 2021].

8. Babuna, P., Yang, X., Gyilbag, A., Awudi, D. A., Ngmenbelle, D., Bian, D. (2020). The impact of COVID-19 on the insurance industry. IJERPH. 17 (16): 57-66.

9. [BPS] Central Bureau of Statistics. (2021). Indonesia's economy in the first quarter of 2021 fell 0.74 percent. https://www.bps.go.id/pressrelease/2021/05/05/1812/ekonomiindonesia-triwulan-i-2021-turun-0-74-persen--y-on-y-.html. [July 19, 2021]. 
10. Budiman, H., Seminar, K. B., Saptono, I. T. (2020). Formulation of digital banking development strategy (case study of bank abc). JABM 6(3): 489-500.

11. David, F. R., \& David, F. R. (2016). Strategic Management: A Competitive Advantage Approach. Ed k-15. Puspitasari N, Pupitasari LN, translators. Jakarta: Salemba Empat.

12. Dewi, N. R., Sukardi, Djohar, S. (2018). Formulation of the $X Y Z$ salon business development strategy. JABM 4(3): 365-376.

13. Grant, R., Butler, B., Orr, S., Murray, S. (2014). Contemporary strategic management (pp.174-177). Milton (AUS): Wiley Godet M, Durance P, Gerber A. 2007. Strategic foresight la prospective: use and misuse of scenario building. Paris (FR): Research Working Paper.

14. Haque, A., Mohona, N. T., Sultana, S., Kulsum, U. (2021). The impact of COVID-19 on the insurance industry of Bangladesh. Indian Journal of Finance and Banking 6(1): 73-88

15. [IAI] Indonesian Insurance Association. (1994). Statement of Financial Accounting Standards (PSAK) Number 28 Accounting for Loss Insurance.

16. [Ministry of Health] Ministry of Health of the Republic of Indonesia. (2020). Guidelines for the prevention and control of coronavirus disease (COVID-19). https://covid19.kemkes.go.id/protokol-covid-19/kmk-no-hk-01-07-menkes-413-2020-ttgpedoman-pensepsian-dan-pentangan-covid-19/\#. X6ADAVBS_IU. [2 November 2020].

17. Kemp, S. (2021). Digital 2021: the latest insights into the 'state of digital'. https://wearesocial.com/blog/2021/01/digital-2021-the-latest-insights-into-the-state-ofdigital. [17 September 2021].

18. Manuel, E. G. (2016). The five competitive forces of the insurance and pension funds industry for the Angolan case. Arabian J Bus Manag Review 6(6):1-5.

19. Nofrizal. (2017). Strategy to grow and compete in the insurance industry (case study on BPJS Ketenagakerjaan Pekanbaru). BENEFITS Journal of Management and Business 2(1): 78-91.

20. [OJK] Financial Services Authority. (2020). National Survey of Financial Literacy and Inclusion 2019. https://www.ojk.go.id/id/berita-dan-activity/publikasi/Pages/SurveiNasional-Literasi-dan-Inclusion-Keuangan-2019.aspx. [August 1, 2021].

21. Parvathi, V., Lalitha, C. (2021). Impact of COVID-19 pandemic on the indian insurance sector. Perspectives on Business Management \& Economics 4: 60-65.

22. Prakoso, A. (2020). Analysis of the competitive strategy of PT Asuransi Jiwa Gerali Indonesia to win the competition [thesis]. Yogyakarta: Gadjah Mada University.

23. Stojkoski, V., Jolakoski, P., Ivanovski, I. (2020). The short-run impact of COVID-19 on the activity in the insurance industry in the Republic of North Macedonia. ArXiv.

24. Sulastri, Rifin, A., Sanim, B. (2018). Life insurance development strategy. JABM 4(1):4451.

25. Thompson, J., Scoot, J. M., Martin, F. (2017). Strategic management: awareness and change. Andover: Hampshire Cengange Learning.

26. [UU] Law of the Republic of Indonesia Number 40 of 2014 concerning Insurance.

27. Utomo, P., Baga, L. M., Djohar, S. (2019). Strategy for performance improvement at building division of PT Hutama Karya (Persero) in conditions of construction building business competition. RJOAS 8(92): 227-234.

28. Wandebori, H. (2019). Proposed business strategy improvement through service quality gap model to increase membership coverage of BPJS employment. Journal of Theoretical and Applied Management 12(3):189-206.

29. Wandrial, S. (2011). The company's internal analysis (strengths \& weakness) uses the concept of resource-based view of the firm with the VRIO framework. Binus Business Review 2(2):627:637.

30. Wang, Y., Zhang, D., Wang, X., Fu, Q. (2020). How does COVID-19 affect China's insurance market. Emerging Markets Finance and Trade 56(10):2350-2362.

31. [WHO] World Health Organization. (2020). WHO coronavirus disease (COVID-19) dashboard. https://covid19.who.int/. [1 November 2020].

32. Worku, A., Mersha, D. (2020). The effect of COVID-19 on insurance industry in Ethiopia. HAJBE Special Issue I: 39-44. 